\title{
The Effect of Hydraulic Retention Times and Loading Rates on the Removal of Pollutants from Fish Processing Wastewater by Anaerobic Process
}

\author{
Dao Khanh Chau and Tran Thanh Dai \\ Faculty of Health and Applied Sciences, Dong Nai Technology University, Nguyen Khuyen Street, Trang Dai ward 810000, Bien \\ Hoa city, Dong Nai province, Vietnam
}

\begin{abstract}
Anaerobic treatment model treats fish processing wastewater to be necessary for a small and medium factory that is very popular in Vietnam and other countries. Several techniques have been proposed. However, they are quite expensive and hard to operate, especially in remote areas. In this study, the hydraulic retention times (HRT) including 3, 5, and 7 hours with a various organic loading rate of 1.5 to $6.5 \mathrm{~kg} \mathrm{COD} / \mathrm{m}^{3} /$ day were investigated. Biomass concentration as mix-liquor volatile suspended solid (MLVSS) in the model is at 6,000 to $9,000 \mathrm{mg} / \mathrm{L}$. On the basis of the result the optimal HRT with a $4.0 \mathrm{~kg} \mathrm{COD} / \mathrm{m}^{3} / \mathrm{day}$ organic loading rate was 8 hours which BOD5, COD removal efficiency were 92.18, 87.36 percent respectively. By the end of the optimal hydraulic retention times, the total methane gas volume as a by-product was collected with 2.6 liters.
\end{abstract}

Key words: Wastewater treatment, anaerobic process, hydraulic retention time, organic loading rate.

\section{Introduction}

Global consumption of fish has doubled since 1973, and the developing world has been responsible for nearly all of this growth. The total per capita consumption of food fish in the developing world has increased from $7.3 \mathrm{~kg} / \mathrm{capita} /$ year to 14.0 $\mathrm{kg} / \mathrm{capita} /$ year from 1973 to 1997 while it has come down from $22.6 \mathrm{~kg} / \mathrm{capita} /$ year to $21.7 \mathrm{~kg} / \mathrm{capita} /$ year from 1973 to 1997 in the case of the developed world. The projected per capita consumption of food fish in the year 2020 is estimated to be $16.2 \mathrm{~kg} /$ capita/year and $21.5 \mathrm{~kg} / \mathrm{capita} /$ year for the developing world and developed world, respectively [1].

Water consumption in a fish-processing industry and high-strength wastewater from such an industry are of great concern world-wide. Liquid effluent regulations are becoming more stringent day by day. The anaerobic treatment process can be considered as

Corresponding author: Dao Khanh Chau, Ph.D., research field: wastewater treatment and reuse. the core method of a resource preservation and environmental protection (EPRP) technology, and it, therefore, represents - combined with other proper methods - the advanced sustainable technology society urgent needs. Despite the persisting reluctant attitude of the established wastewater pollution control world, anaerobic treatment is assured of increased usage in the future, the more so because the potentials of the method are far bigger than expected a few years ago [2]. The big benefits of the anaerobic wastewater treatment concept compared to conventional aerobic methods should be known and will not be discussed here again. Accepting that the anaerobic treatment principle is a pre-treatment method, at the present state of knowledge, little if any serious drawbacks can be brought up against it any more. Previously mentioned drawbacks have vanished almost completely, like its presumed low stability.

The anaerobic treatment of wastewaters from the seafood-processing industry was studied in a $15 \mathrm{~m}^{3}$ industrial pilot-plant. These effluents have a high 
organic content (10-60 g COD/liter), with protein percentages between 25 and $70 \%$, and a salinity similar to sea water: sodium $(5-12 \mathrm{~g} / \mathrm{L})$, chloride $(8-19 \mathrm{~g} / \mathrm{L})$ and sulphate $(0.6-2.7 \mathrm{~g} / \mathrm{L})$. This high concentration of salts, together with the production of sulphide and ammonia due to sulphate reduction and protein breakdown, respectively, produces important inhibitory/toxic effects on non-adapted biomass. After an initial start-up procedure, where the acclimation of the biomass was the objective, $70-90 \%$ organic matter removal was achieved [3].

The performance of one-step UASB reactors treating fish processing wastewater of different lipid levels was determined using artificially generated influent simulating that of the canning of sardines and tuna. The organic loading rates (OLR) and the hydraulic retention times (HRT) were 5-8 g COD $\mathrm{L}^{-1} \cdot \mathrm{d}^{-1}$ and 11-12 hours, respectively. In treating a wastewater that contains $3-4 \mathrm{~g} \cdot \mathrm{L}^{-1}$ total COD of which $5-9 \%$ was lipids, the COD removal and conversion to methane were ca. $78 \%$ and $61 \%$, respectively [4].

\section{Experiments}

\subsection{Lab-Scale Model Setup}

The system was designed with a 7-litter anaerobic tank used in this study and was made with a column of $120 \mathrm{~mm}$ inner diameter, a total volume of 7 liters including reaction section of 6.5 liters and a gas zone of 0.5 liters. The wastewater was introduced at the bottom of the reactor through a tube of about $2 \mathrm{~mm}$. Sludge concentration in the reactor was $12.5 \mathrm{~g} \mathrm{SS} / \mathrm{L}$ (11.3 g VSS/L).

The methane gas was collected to a column of 5 liters tank that was filled with sodium hydroxide solution (5 percent) to absorb carbon dioxide $\left(\mathrm{CO}_{2}\right)$ and hydrosulfite $\left(\mathrm{H}_{2} \mathrm{~S}\right)$ gases. Influent and effluent samples were analyzed for $\mathrm{pH}$, alkalinity, COD, BOD5, suspended solid (SS).

The system was started up in 30 days at $1.0 \mathrm{~kg}$
$\mathrm{COD} / \mathrm{m}^{3} / \mathrm{d}$ before analyzing all parameters.

\subsection{Methods of Analysis}

COD, BOD5, SS, VSS, TN, TP were measured depending on Standard Method (1993), respectively. SS in effluent and VSS in sludge samples were measured by total suspended solids dried at $103-105^{\circ} \mathrm{C}$ and volatile solids ignited at $550^{\circ} \mathrm{C}$ based on Standard Method (1993), respectively.

\section{Results and Discussions}

The model was operated continuously for 120 days (including 30 days for startup), one loading rate each month, from 1.5 to $6.5 \mathrm{~kg} \mathrm{COD} / \mathrm{m}^{3} / \mathrm{d}$.

Figs. 1 and 2 show that there was little change in BOD and COD of raw wastewater, the average of COD inlet was $1,164 \mathrm{mg} / \mathrm{L}$ during all operating time while $887 \mathrm{mg} / \mathrm{L}$ with BOD. At first OLR1 (1.5 $\mathrm{COD} / \mathrm{m}^{3} / \mathrm{d}$ ), the average outlet of COD was $131 \pm 16$ $\mathrm{mg} / \mathrm{L}$ and the efficiency removal remained stable at around over $88 \%$, that was significantly high. This figure of BOD was nearly 90\%. Regarding OLR2 (3.5 $\mathrm{COD} / \mathrm{m}^{3} / \mathrm{d}$ ), it was clear that the outlet of both COD and BOD was slightly higher than OLR1 with $146 \pm$ $16 \mathrm{mg} / \mathrm{L}$ and $103 \pm 10 \mathrm{mg} / \mathrm{L}$, respectively. It could be seen that the efficiency removal reached $87 \pm 2 \%$ and $89 \pm 2 \%$, respectively.

Fig. 3 unveils that the model could remove SS efficiently. The concentration of inlet SS often maintained at around over $500 \mathrm{mg} / \mathrm{L}$ while the outlet was stable at $80 \mathrm{mg} / \mathrm{L}$ and tended to increase through OLRs.

Methane gas is a by-product that appears in any anaerobic process using bacteria and people often utilize this kind of gas for producing electricity, lighting, burning, etc. Fig. 4 shows that during the operating period, this system produced about 300 $\mathrm{cm}^{3} / \mathrm{d}$ at the first OLR and rose dramatically to 450 $\mathrm{cm}^{3} / \mathrm{d}$ before going down again to around $310 \mathrm{~cm}^{3} / \mathrm{d}$. 
The Effect of Hydraulic Retention Times and Loading rates on the Removal of Pollutants from Fish Processing Wastewater by Anaerobic Process

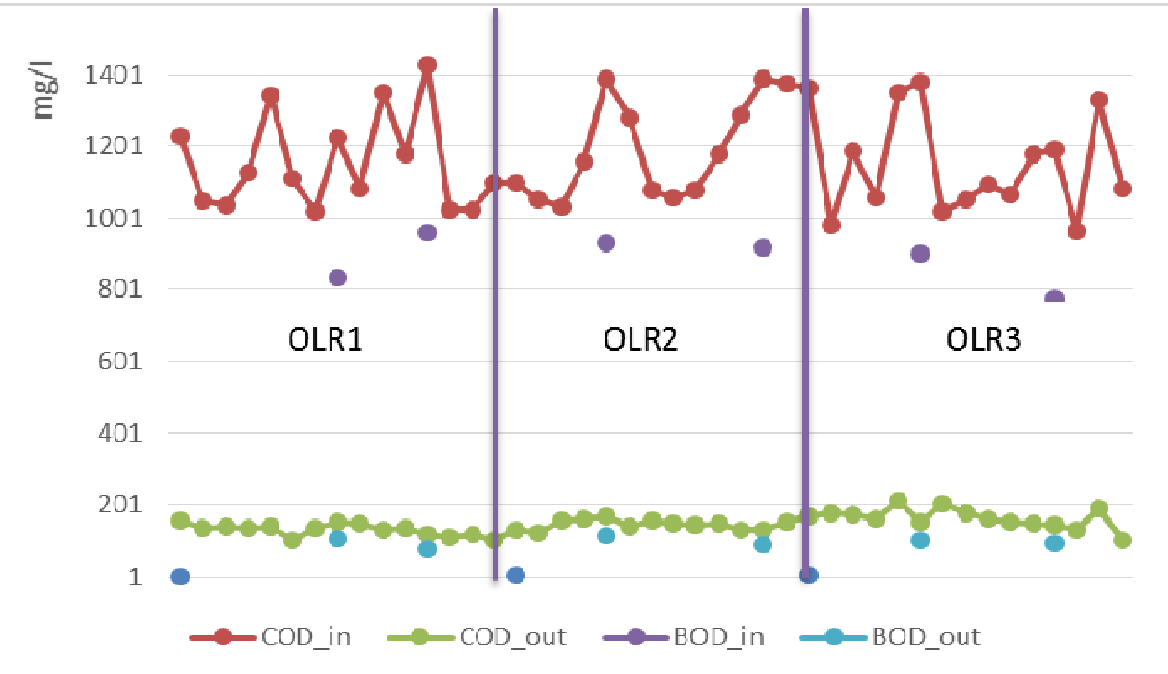

Fig. 1 The changes in COD, BOD inlet, and outlet through 3 OLRs.

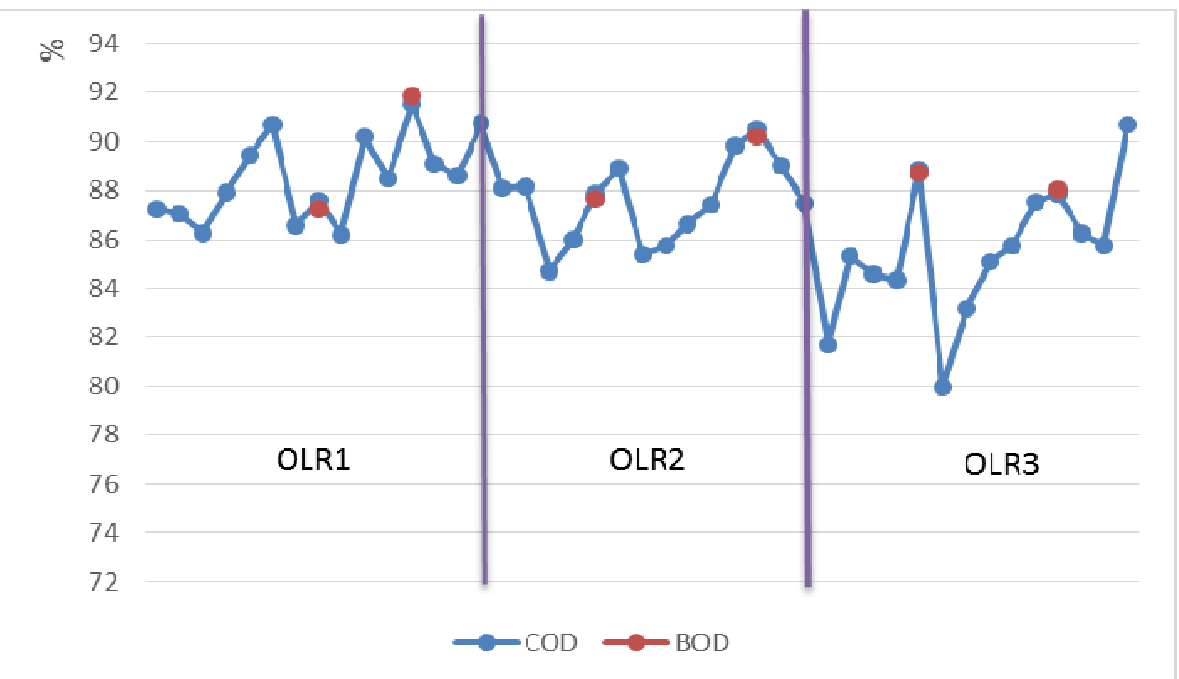

Fig. 2 The changes in COD, BOD efficiency through 3 OLRs.

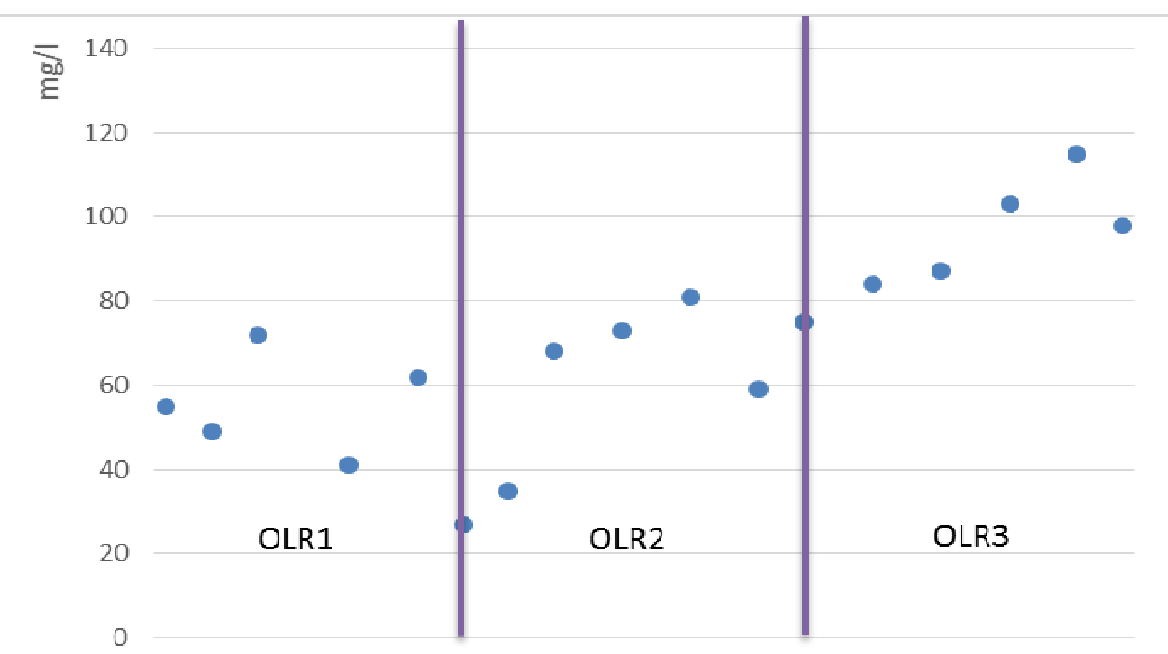

Fig. 3 The changes in SS outlet through 3 OLRs. 


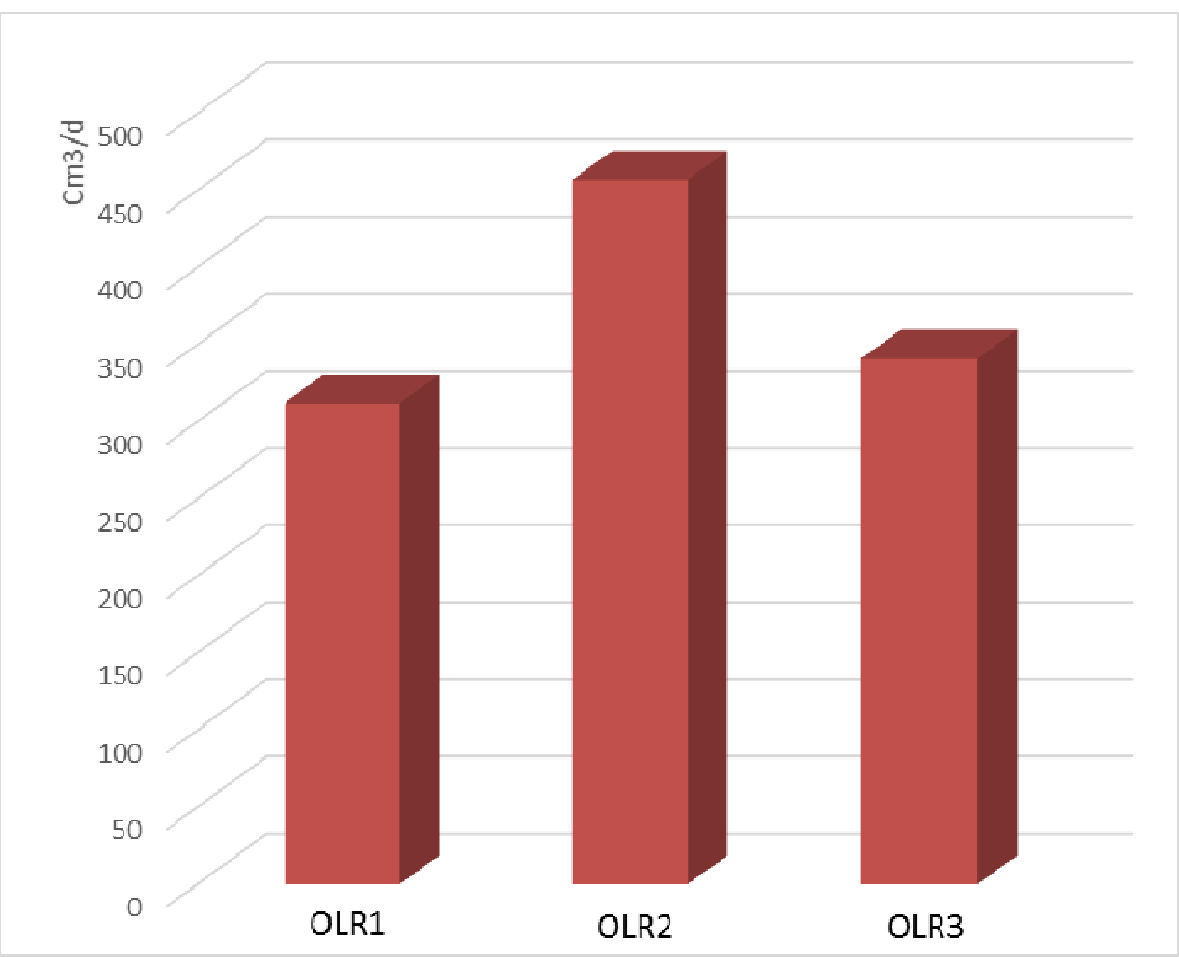

Fig. 4 The changes in methane gas producing as by-product through 3 OLRs.

\section{Conclusions}

The results achieved in this research revealed that the anaerobic process could be applied as an effective solution for fish processing wastewater in tropical regions such as Vietnam, India where fishery resource plays an important role in the economy. Based on the results, here the following conclusions could be drawn:

The optimum HRT and OLR for treating fish processing wastewater through the anaerobic process were $3.5 \mathrm{~kg} \mathrm{COD} / \mathrm{m}^{3} / \mathrm{d}$ and 5 hours. As these conditions, the average removal efficiency for COD and BOD5 was 87 and 89 percent, respectively. The SS concentration effluent is often below $120 \mathrm{mg} / \mathrm{L}$. The methane volume produced of $450 \mathrm{~cm}^{3} / \mathrm{d}$.

\section{Acknowledgements}

The author wishes to thank laboratory of Health and
Applied Sciences Faculty, colleagues and students at Dongnai Technology University for helping during the research.

\section{References}

[1] Chowdhury, P., Viraraghavan, T., and Srinivasan, A. 2010. "Biological Treatment Processes for Fish Processing Wastewater-A Review." Bioresour Technol 101 (2): 439-49.

[2] Lettinga, G., Field, J., Zeeman, G., and Pol, L. W. H. 1997. "Advanced Anaerobic Wastewater Treatment in the Near Future.” Wal. Sci. Tech 35 (10): 5-12.

[3] Omil, F., Méndez, R., and Lema, J. M. 1995. “Anaerobic Treatment of Saline Wastewaters under High Sulphide and Ammonia Content." Bioresour Technol 54 (3): 269-78.

[4] Paluenzuelarollon, A., Zeeman, G., Lubberding, H. J., Lettinga, G., and Alaerts, G. J. 2002. "Treatment of Fish Processing Wastewater in A One- or Two-Step Upflow Anaerobic Sludge Blanket (UASB) Reactor." Wal. Sci. Tech 45 (10): 207-12. 